Liliana Podwika

Studentka Uniwersytetu Pedagogicznego im. Komisji Edukacji Narodowej w Krakowie

\title{
Analiza dotychczasowych doświadczeń w stosowaniu ustawy o bezpieczeństwie imprez masowych i refleksje na przyszłość
}

\author{
https://doi.org/10.25312/2391-5110.14/2019_05lp
}

\begin{abstract}
Streszczenie
Artykuł porusza tematykę organizowania i zabezpieczania imprez masowych. Autorka rozpoczęła analizę od wyjaśnienia pojęcia imprezy masowej oraz dokonała pewnego wstępu historycznego do zagadnienia, jednocześnie poruszając kwestie tworzonych w starożytności regulacji prawnych mających na celu zapewnienie bezpieczeństwa. W kolejnej części pracy została omówiona polska ustawa o bezpieczeństwie imprez masowych oraz jej ewolucja. Wyszczególniono także inne akty prawne, będące jej uzupełnieniem. W zakończeniu zwrócono uwagę na kontrowersje wskazujące na konieczność nowelizacji tej ustawy. Zadano kilka pytań zmuszających czytelnika do refleksji nad omawianym tematem. Praca ma za zadanie pokazać, iż - mimo licznych nowelizacji - ustawa nie jest jeszcze sprecyzowana wystarczająco jasno i stwarza różne możliwości interpretacji.
\end{abstract}

Słowa kluczowe: impreza masowa, impreza, zabezpieczanie imprez, bezpieczeństwo

\section{Analysis of the application of the law on safety at mass events and reflections on the future}

\section{Summary}

This article considers safety at mass events. The concept and history of the 'mass event' are outlined. The author discusses legal regulations related to safety at mass events. She 
describes the Polish law on safety at mass events and its evolution, and provides details of other laws that complement it. Attention is drawn to controversies which suggest that there is a need to amend this law. Several rhetorical questions encourage the reader to reflect on the issue. The article shows that, despite numerous amendments to the law on safety at mass events, the law is not yet clear enough and creates opportunities for different interpretations.

Keywords: mass event, show, safety

\section{Wprowadzenie}

Do imprez masowych odnosi się wiele sformułowań: „rozrywka”, „dobra zabawa”, „spędzanie czasu z innymi ludźmi”, „integracja”. Każdy człowiek ma inne wyobrażenie na ten temat i tworzy różne, często całkiem nieadekwatne do rzeczywistości definicje tego pojęcia. Imprezy masowe, tak bardzo potrzebne człowiekowi do miłego spędzania czasu, muszą być organizowane i zabezpieczane w odpowiedni sposób. Należy zatem dostosować się do pewnych ogólnie przyjętych reguł, aby wydarzenie było pod każdym względem sukcesem. Ustawodawca, tworząc prawo, kierował się dobrem ogółu i nie zapomniał o widowiskach gromadzących rzeszę ludzi, dlatego też niniejszy artykuł zawiera ogólny zarys historycznego tworzenia się prawa związanego na różne sposoby z imprezami masowymi (od czasów antycznych cywilizacji po czasy współczesne) i analizę polskiej ustawy o bezpieczeństwie imprez masowych. Dr hab. Grzegorz Krawiec, prof. UP, dr hab. Sławomir Tkacz, prof. UŚ oraz dr hab. Aleksandra Wentkowska w bardzo ciekawy sposób dokonali wykładni przepisów nowelizujących tę ustawę już w 2013 roku .

W Polsce w ostatnich latach organizowanych jest coraz więcej wydarzeń o charakterze masowym. Dbałość o bezpieczeństwo w trakcie ich przebiegu jest bardzo ważną kwestią. W związku z tym celem zasadniczym artykułu jest analiza ewolucji ustawy o bezpieczeństwie imprez masowych oraz omówienie kontrowersyjnych kwestii z nią związanych. Główną tezą pracy jest stwierdzenie, iż zachodzą przesłanki wskazujące na konieczność nowelizacji ustawy o bezpieczeństwie imprez masowych. Dane zawarte w niniejszej pracy zostały zaczerpnięte ze strony NIK oraz wywiadów przeprowadzonych z policją i organizatorami wspomnianych imprez. Jednak w głównej mierze artykuł opiera się na analizie aktów prawnych.

\section{Geneza imprez masowych i regulacji prawnych z nimi związanych}

Ludzie już od najmłodszych lat szukają rozrywki. Aby oderwać się od monotonii codzienności, uczestniczą w różnego rodzaju balach, widowiskach, przyjęciach. Pojęcia te są niczym

${ }^{1}$ G. Krawiec, S. Tkacz, A. Wentkowska, Ustawa o bezpieczeństwie imprez masowych: wykładnia przepisów nowelizujących w świetle regulacji europejskich, Biuro Rzecznika Praw Obywatelskich, Warszawa 2013. 
innym jak synonimami imprezy². Im więcej ludzi, tym lepsza zabawa. Polski ustawodawca zdefiniował imprezę masową jako imprezę masową artystyczno-rozrywkową, masową imprezę sportową oraz mecze piłki nożnej ${ }^{3}$. Trzy różne nazwy, a co za tym idzie - trzy różne sytuacje i trzy różne charakterystyki wydarzeń. Co jednak jest ich istotą? Organizując imprezę masową, pierwszą z podstawowych informacji, na jakich trzeba się skupić, jest z pewnością liczba miejsc, jakie organizator musi udostępnić uczestnikom. Kolejnym istotnym elementem są obiekty, w których miałoby odbyć się dane wydarzenie. W tabeli 1 zostały przedstawione podstawowe dane pomagające w zakwalifikowaniu widowiska do imprez masowych.

Tabela 1. Minimalna liczba miejsc, jakie organizator jest zobowiązanych udostępnić uczestnikom imprez masowych

\begin{tabular}{|l|c|c|c|}
\hline \multirow{2}{*}{ Miejsce imprezy } & \multicolumn{2}{c|}{ Rodzaj imprezy masowej } \\
\cline { 2 - 4 } & $\begin{array}{c}\text { Artystyczno-rozryw- } \\
\text { kowa }\end{array}$ & Sportowa & $\begin{array}{c}\text { Mecz piłki } \\
\text { nożnej }\end{array}$ \\
\hline $\begin{array}{l}\text { Stadion lub inny obiekt niebędący budynkiem bądź teren } \\
\text { stwarzający możliwości do przeprowadzenia imprezy }\end{array}$ & 1000 & 1000 & 1000 \\
\hline $\begin{array}{l}\text { Hala sportowa lub inny budynek stwarzający możliwości } \\
\text { do przeprowadzenia imprezy }\end{array}$ & 500 & 300 & 1000 \\
\hline
\end{tabular}

Źródło: opracowanie własne na podstawie art. 3 ustawy o bezpieczeństwie imprez masowych.

Istnieją jednak imprezy, które - mimo spełnienia zawartych w tabeli warunków - nie są uznawane za imprezy masowe. Należą do nich wszystkie wydarzenia organizowane dla niepełnosprawnych sportowców; w teatrach, filharmoniach, kinach, operach, bibliotekach oraz muzeach i innych podobnych miejscach; w szkołach bądź obiektach oświatowych przez osoby uprawnione do zarządzania tymi miejscami; w formie rywalizacji sportowej dzieci i młodzieży; przez pracodawców dla pracowników, tylko gdy miejsce imprezy jest wykorzystywane podczas imprezy zgodnie z jego przeznaczeniem; na wyodrębnionym do sportu rekreacyjnego terenie otwartym, mające charakter dostępny dla wszystkich i nieodpłatny ${ }^{4}$.

Dokładne określenie, kiedy odbyła się pierwsza impreza masowa, jest niemożliwe, ponieważ nie zawsze dokumentowano tego typu wydarzenia. Starożytni Grecy odnotowali rok 776 p.n.e. jako datę ,pierwszych” igrzysk olimpijskich ${ }^{5}$. Aktualnie uznaje się tę datę za początek wielkich, gromadzących ludzi widowisk. Co ciekawe, przepych, jaki towarzyszył organizacji imprez masowych oraz ich spektakularność oddziaływały nie tylko na ogólne zadowolenie ludzi. Waga wydarzeń niejednokrotnie była znacznie większa, jak na przykład w przypadku greckiego uczonego Timajosa, który zmienił chronologię historii ${ }^{6}$. Wcześniej za najważniejszy moment w dziejach Grecji uznawano datę zdobycia

${ }^{2}$ M. Bańko (red.), Stownik języka polskiego PWN, t. 1, Wydawnictwo Naukowe PWN, Warszawa 2000, s. 531.

${ }^{3}$ P. Suski, Zgromadzenia i imprezy masowe, wydanie 2, LexisNexis, Warszawa 2010, s. 303.

${ }^{4}$ L. Dyduch, Imprezy masowe i zgromadzenia w sprawach publicznych-aspekty prawne i praktyczne, „Kwartalnik Policyjny” 2016, R. X, nr 4(39), s. 3.

${ }^{5}$ S.G. Miller, Starożytni Olimpijczycy. Sportowe życie antycznej Grecji, Państwowy Instytut Wydawniczy, Warszawa 2004, s. 35.

${ }_{6}^{6}$ Polski Komitet Olimpijski, Igrzyska starożytne, http://www.olimpijski.pl/pl/78,igrzyska-starozytne. html, [dostęp: 23.11.2019]. 
Troi i to ona była wyznacznikiem czasu. Igrzyska olimpijskie gromadziły ogromną liczbę ludzi w jednym miejscu, co wiązało się z wystąpieniem ewentualnych zagrożeń. Królowie Elidy, Plisy i Sparty, w celu zapobiegania niebezpiecznym sytuacjom podczas przebiegu jednych z najbardziej znaczących w tych czasach imprez, zawarli sojusz o pokoju bożym. Niniejsze porozumienie zobowiązało wszystkich do heromeni, co oznacza zawieszenie broni. Powstała wtedy też nazwa olimpiada, oznaczająca okres 4 lat pomiędzy kolejnymi igrzyskami ${ }^{7}$. Literatura wskazuje jednoznacznie, iż czas ten miał na celu rozrywkę i jednoczenie społeczności greckiej. Zawieszenie działalności przez sądy to jeden z przykładów odzwierciedlających ogromne znaczenie imprez masowych dla społeczeństwa doby antyku. Sojusz zawarty między wspomnianymi królami nie był jednak wystarczającą regulacją zapewniającą bezpieczeństwo. Przykładem wykroczenia była sytuacja z 364 r. p.n.e. Chęć „przejęcia” imprezy przez Arkadów i Pisańczyków i zastąpienia organizatorów była silniejsza od ustaleń między królami. Miasto Olimpia zostało recypowane ${ }^{8}$. W wyniku zamieszek wiele osób straciło życie, a uregulowanie pewnych zasad stało się konieczne.

Warto w tym miejscu zwrócić uwagę na starożytny Rzym. Chęć przypodobania się obywatelom skłoniła patrycjuszy do organizowania większych, lepszych i bardziej hucznych imprez, co wpłynęło pozytywnie na rozwój igrzysk. Wykorzystywano je często w sferze politycznej, by zyskać przychylność zaproszonych gości. Starożytny Rzym regulował w swoim prawie wielkości takich imprez'. Rozmach, z jakim organizowano widowiska, był niesamowity. Liczba planowanych przedsięwzięć w ciągu roku często była większa od liczby dni pracujących. Podobnie jak w Grecji czynności publiczno-administracyjne były zawieszane na czas imprezy masowej ${ }^{10}$, co może świadczyć o priorytetach ówczesnego społeczeństwa. Budowano wtedy potężne gmachy stadionów, zwane circusami. Najbardziej znany, znajdujący się w Rzymie Circus Maximus mógł pomieścić aż 250000 osób chcących oglądać wyścigi rydwanów czy walki gladiatorów. Niejednokrotnie dochodziło do rywalizacji również na trybunach - w 532 roku doszło do buntu w Konstantynopolu ${ }^{11}$. Był on zapoczątkowany walkami kibiców dwóch przeciwnych drużyn. W starożytnym Rzymie kładziono nacisk na bezpieczeństwo przebiegu imprez masowych. Pierwszym wartym wyróżnienia przykładem jest architektura. Otwarte w 80 roku Koloseum zachwycało swoją wielkością i wspaniałością. Liczne korytarze, schody, przejścia umożliwiały bardzo szybkie przemieszczanie się uczestników wydarzenia, co z pewnością poprawiało bezpieczeństwo imprez. Gmach budowli był w stanie zmieścić aż 50000 ludzi, co na tamte czasy było imponującym wynikiem.

Bezpieczeństwo starano się zapewnić również przez wprowadzenie regulacji prawnych. Pierwsza z nich pojawiła się już w 81 r. p.n.e. Lex Cornelia de sicariis et veneficiis obejmowała bardzo szeroki zakres sankcji za wykroczenia związane z krzywdzącymi działaniami

${ }^{7}$ Z. Porada, Starożytne i nowożytne igrzyska olimpijskie, Krajowa Agencja Wydawnicza, Kraków 1980, s. 30-31.

${ }^{8}$ Polski Komitet Olimpijski, dz. cyt.

9 J. Ciechanowicz, Rzym-ludzie i budowle, Państwowy Instytut Wydawniczy, Warszawa 1987, s. 75.

${ }^{10}$ B. Sitek, Bezpieczeństwo imprez masowych w antycznym Rzymie na tle wspótczesnych rozwiąań, „Studia Ełckie” 2011, nr 13, s. 336.

11 S. James, Starożytny Rzym. Oto jedna z najwspanialszych cywilizacji świata i ludzie, którzy ja tworzyli - od cesarza do niewolnika, Arkady, Warszawa 1994, s. 34-35. 
przeciwko ludziom bądź dorobkowi ich życia. Do odpowiedzialności za przewinienia mógł być pociągnięty każdy, bez względu na płeć, status, wiek ${ }^{12}$. W wyniku procesu legislacyjnego między 78 a 63 r. p.n.e. pojawiła się kolejna ustawa - lex Plautia de vi. Dokument ten powołał do istnienia quaestio, czyli trybunał właściwy do określania, jakie zachowania należą do niszczących lub negatywnie wpływających na publiczny pokój ${ }^{13}$. Podsumowując, sytuacje z użyciem siły, takie jak wszczynanie zamieszek, od tego momentu były rozpoznawane przez wyznaczony do tego organ i traktowane jako wykroczenia. Dokonano również zmian w samym przebiegu imprez masowych i ustawą z 67 r. p.n.e., zwaną lex Rosicia theatralis, podzielono widownię na trzy sfery, oddzielając w ten sposób ekwitów od senatorów i pozostałych widzów. Regulacja ta miała na celu zmniejszenie szansy na ewentualne konfrontacje, sprzeczki pomiędzy często nielubiącymi się sferami społecznymi ${ }^{14}$. Kolejną istotną częścią systemu prawnego była lex Iulia de vi publica. Był to wydany przez Juliusza Cezara akt końca republiki, poruszający kwestie zakłócania porządku publicznego. Był to katalog wykroczeń, do których między innymi można było zaliczyć destabilizowanie pracy urzędników, wywoływanie niepokoju wśród ludzi czy udaremnianie wykonania kary.

Najbardziej znaczący wpływ na bezpieczeństwo imprez masowych miała jednak lex Iulia de vi privata. Skupienie się na człowieku jako jednostce było podkreśleniem wartości każdego życia ludzkiego. Naruszenia praw drugiego człowieka były traktowane jako wykroczenia podlegające sankcji. Pojęcie nietykalności cielesnej nabrało większego znaczenia, a uprowadzenia, okaleczenia stały się czymś zabronionym ${ }^{15}$.

Igrzyska olimpijskie przestały być organizowane za sprawą cesarza Teodozjusza I Wielkiego, który w roku 393 n.e. wydał zakaz ich inicjowania. Dwa lata później plemiona gockie zniszczyły Peloponez, rabujące i niszczące jedno z najbardziej znanych miejsc na świecie. W 426 r. n.e. cesarz Teodozjusz II uznał Altis za obszar kultów pogańskich, nakazując spalenie zabytków mogących przypominać o największych starożytnych imprezach masowych. Pozostałości po nich zostały doszczętnie zniszczone około 100 lat później przez trzęsienie ziemi. Tak oto idea rywalizacji olimpijskiej na ponad 1000 lat odeszła w zapomnienie ${ }^{16}$.

W późniejszych latach starożytna Grecja stały się inspiracją dla Pierre’a de Coubertina. Baron urodzony w Paryżu w 1863 roku stał się „ojcem” nowożytnego ruchu olimpijskiego. Podczas nauki, jaką odebrał w jezuickim liceum św. Ignacego w Paryżu, było bardzo głośno o Olimpii, w której przeprowadzano wtedy prace archeologiczne ${ }^{17}$. Podczas pobytu w Anglii młody mężczyzna bardzo szczegółowo zagłębił się w poglądy Thomasa Arnolda i zapragnął wprowadzić pewne zmiany we francuskim szkolnictwie. Chciał, by młodzież nie zgłębiała w szkole jedynie wiedzy, ale by rozwijała się też przez aktywność ruchową. Zafascynowany wpływem gier sportowych na wychowanie młodzieży wierzył, iż uczą one pewnych umiejętności, które są bezcenne w dorosłym życiu ${ }^{18}$. Liczba jego zwolenników

${ }^{12}$ B. Sitek, dz. cyt., s. 333.

13 Tamże.

14 Tamże.

15 Tamże.

${ }^{16}$ Polski Komitet Olimpijski, dz. cyt.

${ }^{17}$ K. Deberny, K. Płoszaj, W. Firek, Błyszczacy sterowiec. Pierre de Coubertin o sporcie i olimpizmie, Polski Komitet Olimpijski, Warszawa 2013, s. 14.

${ }^{18}$ W. Lipoński, Historia sportu, Wydawnictwo Naukowe PWN, Warszawa 2018, s. 475. 
zaczęła rosnąć dzięki jego częstym wizytom w USA i tamtejszym licznym wystąpieniom. Początkowe pragnienia przeprowadzenia jedynie reformy szkolnictwa nie wskazywały na to, iż de Coubertin będzie prężnie działać w sferze sportu i to na arenie międzynarodowej. Podczas jednej z wizyt w USA mężczyzna zetknął się ze sportem widowiskowym. Zauważył wtedy, że takie wydarzenie wywołuje emocje nie tylko wśród osób rywalizujących, ale również wśród widowni. Zaskoczył go rozmiar imprezy masowej oraz zainteresowanie nią. W 1894 roku odbył się Kongres dla Wskrzeszenia Igrzysk Olimpijskich. W tym samym roku powołano oficjalnie Komitet Olimpijski ${ }^{19}$. Ideą, jaka towarzyszyła baronowi, była zdrowa rywalizacja pomiędzy młodzieżą z całego świata. Igrzyska miały jednoczyć. Z uwagi na to, iż w tamtych czasach nie istniało zbyt wiele federacji sportowych o charakterze międzynarodowym, nie było również jednolitych regulaminów. Stosowano się zatem do regulacji najlepiej rozwiniętego pod względem przepisów sportowych państwa, czyli Anglii ${ }^{20}$.

Imprezy masowe kojarzone są z dużą liczbą osób. Każde państwo ma własne regulacje związane z organizacją tego typu wydarzeń. Jeśli jednak dochodzi do imprezy międzynarodowej, organizator zobowiązany jest spełnić dodatkowo inne wymagania poza tymi określonymi przez prawo państwa, na którego terenie ma odbyć się widowisko.

W latach 1983-1984 podczas Zgromadzeń Parlamentarnych Rady Europy zwrócono uwagę na problem występowania niebezpiecznych sytuacji podczas wydarzeń sportowych, a w szczególności przemocy wśród zawodników i widowni. Przyjęto wówczas Rekomendację 963 oraz Rekomendację R (84)8. Pomimo dużej wagi problemu powstałe wówczas dokumenty nie były w żaden sposób wiążące. Dopiero sytuacja z meczu piłki nożnej na stadionie Heysel w Brukseli 29 maja 1985 roku zmusiła do konkretnych zmian legislacyjnych. Bezpieczeństwo imprez masowych stało się tematem pierwszoplanowym. Dla całego świata ważne było, aby nigdy więcej nie doszło do podobnej sytuacji jak w Belgii. Podczas wspominanego meczu kibice wszczęli bójkę. Sytuacji przyglądali się ludzie z całego świata, ponieważ mecz był emitowany na żywo w telewizji. Tego dnia zginęło 39 osób, 670 zostało rannych ${ }^{21}$.

Niedługo po tym zdarzeniu - w sierpniu 1985 roku w Strasburgu Rada Europy przyjęła dokument odnoszący się do przemocy podczas imprez masowych. Była nim Konwencja nr $120^{22}$. Z uwagi na ratyfikację dokumentu sygnatariusze musieli dostosować panujące w ich państwach przepisy tak, aby były zgodne z konwencją ${ }^{23}$. Polska również musiała dokonać zmian legislacyjnych. W ten oto sposób weszła w życie Ustawa z dnia 22 sierpnia 1997 roku o bezpieczeństwie imprez masowych. Dokument, oprócz ogólnych informacji na temat warunków wydawania zezwolenia, obowiązków i uprawnień organizatora, konsekwencji za nieprzestrzeganie ustawy, odnosi się również do uczestników. Przykładem

19 T. Daszkiewicz, Twórca nowożytnych igrzysk olimpijskich, [w:] Pierre de Coubertin (red.), Oda do sportu, Spółka Wydawnicza Heliodor, Warszawa 1996, s. 44.

${ }^{20}$ W.K. Osterloff, Historia sportu, Instytut wydawniczy Nasza Księgarnia, Warszawa 1976, s. 40.

${ }^{21}$ R. Kopczyk, Bezpieczeństwo imprez masowych w świetle przepisów unijnych, s. 5-6, http://robertgrzeszczak.bio.wpia.uw.edu.pl/files/2015/03/BEZPIECZE\%C5\%83STWO-IMPREZ-MASOWYCH-W -\%C5\%9AWIETLE-PRZEPIS\%C3\%93W_R.-Kopczyk.pdf [dostęp: 23.11.2019].

${ }^{22}$ Council of Europe, European Convention on Spectator Violence and Misbehaviour at Sports Events and in particular at Football Matches, https://rm.coe.int/168007a086 [dostęp: 23.11.2019].

${ }^{23}$ R. Kopczyk, dz. cyt., s. 5-6. 
są między innymi zakazy stadionowe czy też identyfikacja widzów ${ }^{24}$. Literatura wskazuje, iż obostrzenia w prawie miały wpływać pozytywnie na wzrost bezpieczeństwa imprez masowych.

\section{Polskie regulacje prawne dotyczące imprez masowych}

Intensywny rozwój różnych dziedzin życia przyczynił się do wzrostu możliwości związanych z organizacją i zabezpieczaniem imprez masowych. Bezpieczeństwo, jako jedno z podstawowych zadań każdego państwa, zobligowało między innymi Polskę do doskonalenia prawa tak, aby sytuacje niebezpieczne były minimalizowane. Charles Monning określił bezpieczeństwo jako ,wolność od zagrożeń, strachu czy ataku” ${ }^{25}$. Rzeczpospolita w ustawie zasadniczej zwróciła uwagę na wspomniane wcześniej pojęcie. Szeroki zakres znaczeniowy bezpieczeństwa zmusił ustawodawcę do wyodrębnienia kilku różnych części poświęconych temu zagadnieniu: obywatele (art. 5, art. 230), państwo (art. 45), ekologia (art. 74). Bezpieczeństwo państwa podzielono dodatkowo na wewnętrzne i zewnętrzne (art. 230$)^{26}$.

Imprezy masowe, ze względu na gromadzenie się dużej liczby osób w jednym miejscu, zasłużyły na szczególne traktowanie. Podjęto działania legislacyjne, w wyniku czego powstała Ustawa z dnia 22 sierpnia 1997 r. o bezpieczeństwie imprez masowych ${ }^{27}$. Innowatorska treść dokumentu miała rozwiązać problemy występowania niebezpiecznych sytuacji. Sama organizacja z kolei miała być już dokładnie opisana, co dodatkowo miało wpływać na jakość widowisk. Niestety, założenia odbiegały od rzeczywistości. Pewne niedociągnięcia od razu zostały wychwycone przez organizatorów dużych imprez, w celu pominięcia powinności wykonania wszelkich procedur związanych na przykład z uzyskaniem pozwolenia na widowisko. Dyferencja interpretacyjna pojęcia wprowadziła duże zamieszanie. Ustawa nie wskazała konkretnie, co jest imprezą o charakterze rozrywkowym. Można zatem uznać, iż definicja imprezy masowej nie była w wyczerpujący sposób opisana. W wyniku takich niedociągnięć wielu organizatorów dyskotek dla więcej niż 300 uczestników - mimo iż była to już impreza masowa - nie starało się o pozwolenia na nią i inicjowało wydarzenia. Swoje postępowanie wyjaśniali, twierdząc, że organizowanie spotkań rekreacyjnych nie podlega ustawie $^{28}$. Między innymi na podstawie wskazanego przykładu ustawodawca został zmuszony do wprowadzenia pewnych zmian we wspominanym akcie prawnym. W ten sposób powstała Ustawa z dnia 20 marca 2009 r. o bezpieczeństwie imprez masowych. Wydanie zupełnie nowego dokumentu uzasadniono następująco:

${ }^{24}$ D. Wykrent, Przeglad prawa i administracji. Wybrane aspekty prawne zapewnienia bezpieczeństwa imprez masowych jako jednego z warunków bezpieczeństwa publicznego, Wydawnictwo Uniwersytetu Wrocławskiego, Wrocław 2016, s. 237.

25 J. Stańczyk, Współczesne pojmowanie bezpieczeństwa, Instytut Studiów Politycznych Polskiej Akademii Nauk, Warszawa 1996, s. 16.

${ }^{26}$ Konstytucja Rzeczpospolitej Polskiej z dnia 2 kwietnia 1997 r., Dz.U. z 1997 r. nr 78, poz. 483 ze zm.

${ }^{27}$ Ustawa z dnia 20 marca 2009 r. o bezpieczeństwie imprez masowych, tekst jedn. Dz.U. z 2019 r., poz. 2171.

${ }^{28}$ S. Pieprzny, E. Ura, Udziat organów administracji publicznej w zabezpieczaniu imprez masowych, [w:] ciż (red.), Bezpieczeństwo imprez masowych, RS Druk, Rzeszów 2012, s. 13-14. 


\begin{abstract}
Wspomniana problematyka została uregulowana w ustawie z dnia 22 sierpnia 1997 r. o bezpieczeństwie imprez masowych, która była już wielokrotnie nowelizowana. W obecnym kształcie, po nowelizacji z dnia 6 lipca 2007 r., przepisy ww. ustawy utraciły wewnętrzną spójność, nie przystając do innych uregulowań i uniemożliwiając skuteczne stosowanie prawa wobec narastającego zjawiska chuligaństwa stadionowego ${ }^{29}$.
\end{abstract}

Wyszczególnić można dwa zakresy niniejszej regulacji: podmiotowy i przedmiotowy. Pierwszy z nich obejmuje obowiązki i uprawnienia, począwszy od organizatora, przez wszystkie osoby przyczyniające się do zapewnienia bezpiecznego przebiegu imprezy, kończąc na uczestnikach. Właściwi miejscowo komendanci policji oraz państwowej straży pożarnej, a także kierownicy pogotowia ratunkowego i państwowego inspektora sanitarnego według nowej ustawy zobligowani są do zaopiniowania imprezy. Opinie takie tworzone są w celu zapewnienia bezpieczeństwa na najwyższym możliwym poziomie. Wymienione wcześniej podmioty podają zarówno ilość środków potrzebnych do zabezpieczenia terenu widowiska, jak i liczbę osób koniecznych do obsługi.

Zakres przedmiotowy skupia się na przykład na pojęciu imprezy masowej. Definicja jest bardzo rozbudowana i eliminuje wcześniej wspominane sytuacje „omijania prawa”. Wyszczególnione zasady zdobywania zezwolenia wyjaśniają całą procedurę od strony organizatora i organu wydającego dokument. Dodatkowo w ustawie zawarte są informacje o gromadzeniu i przetwarzaniu danych, a także opisana odpowiedzialność ciążąca na organizatorze za wszelkie możliwe szkody. Najważniejszą częścią tego aktu prawnego są z pewnością warunki konieczne do tego, aby zapewnione zostało bezpieczeństwo imprezy oraz warunki jego kontrolowania. Warto dodać, iż częściowo zawarte w ustawie zostały również przepisy karne ${ }^{30}$. Zauważalny jest stały wzrost liczby różnych aktów chuliganizmu. Wraz z każdą zmianą ustawy dopisywane są kolejne punkty do katalogu zachowań zakazanych. $Z$ jednej strony świadczy to o szerzącej się deprawacji, z drugiej zaś bardziej restrykcyjne przepisy mogą zwiększyć bezpieczeństwo ${ }^{31}$.

Mimo rozbudowanej treści ustawy o bezpieczeństwie imprez masowych nie można oddzielić jej od reszty prawa. Istnieje wiele ustaw dopełniających jej treść. Część zagadnień nie została w niej zawarta z powodu istniejących już w tej kwestii odrębnych regulacji. Tak więc treść ustawy o bezpieczeństwie imprez masowych, mimo swego fundamentalnego charakteru, nie jest jedynym aktem regulującym organizację i zabezpieczenie widowisk masowych. Istotne kwestie odnoszące się do omawianego zagadnienia zawarte są na przykład w: ustawie o środkach przymusu bezpośredniego i broni palnej, ustawie Kodeks postępowania karnego, ustawie Kodeks wykroczeń, ustawie Kodeks postępowania administracyjnego, ustawie o stanie wyjątkowym, ustawie o ochronie przyrody, ustawie o Państwowej Straży Pożarnej, ustawie o Policji, ustawie o odpowiedzialności podmiotów zbiorowych za czyny zabronione pod groźbą kary i wielu innych. Istnieją również sytuacje, kiedy widowisko mimo iż gromadzi dużą liczbę osób - nie podlega pod ustawę o bezpieczeństwie imprez masowych albo jest z niej wyłączone. Można jednak wyróżnić regulacje, które są dosto-

${ }^{29}$ Sejm VI kadencji, Uzasadnienie projektu ustawy o bezpieczeństwie imprez masowych, druk nr 1074, s. 59, http://orka.sejm.gov.pl/Druki6ka.nsf/0/DA36C82C8CD734EDC12574DA002C0991/\$file/1074.pdf [dostęp: 25.11.2019].

${ }^{30}$ P. Suski, dz. cyt., s. 294-295.

31 C. Kąkol, Prawnokarne aspekty bezpieczeństwa imprez masowych, CeDeWu, Warszawa 2019, s. 30. 
sowane do ustawy o bezpieczeństwie imprez masowych. Przykładami są między innymi: Ustawa z dnia 22 sierpnia 1997 r. o ochronie osób i mienia ${ }^{32}$, Ustawa z dnia 20 czerwca 1997 r. Prawo o ruchu drogowym ${ }^{33}$, Ustawa z dnia 3 lipca 2002 r. Prawo lotnicze ${ }^{34}$, Ustawa z dnia 25 października 1991 r. o organizowaniu i prowadzeniu działalności kulturalnej ${ }^{35}$. Organizacja i zabezpieczenie imprezy masowej wiążą się z wieloma skomplikowanymi działaniami. Organizator powinien być zaznajomiony z wszystkimi potrzebnymi regulacjami prawnymi, a przygotowania do imprezy masowej skrupulatnie zaplanowane.

\section{Kontrowersje związane z imprezami masowymi}

Organizatorzy imprez niejednokrotnie, w celu uproszczenia procedury organizacyjnej, sztucznie ,podciągają" swoje wydarzenie pod inne przepisy niż ustawa o bezpieczeństwie imprez masowych. Taka sytuacja miała miejsce w grudniu 2019 roku, kiedy to Regionalne Centrum Wolontariatu w Gdańsku złożyło wniosek o zgodę na wykorzystanie drogi w sposób szczególny. Sprawa została rozpatrzona pozytywnie i z upoważnienia prezydenta miasta Zespół do Zarządzania Ruchem Urzędu Miasta Gdańska wydał decyzję. Dodatkowo wniosek zaopiniowany został przez komendanta wojewódzkiego policji. Pod koniec grudnia 2018 roku Regionalne Centrum Wolontariatu otrzymało pozwolenie na organizację imprezy i pozytywną opinię policji. Planowane wydarzenie miało odbyć się na Targu Węglowym z zajęciem ulic Targ Węglowy i Bogusławskiego ${ }^{36}$. Artykuł 65 Ustawy z dnia 20 czerwca 1997 r. Prawo o ruchu drogowym brzmi następująco:

Zawody sportowe, rajdy, wyścigi, przewóz osób kolejką turystyczną i inne imprezy, które powodują utrudnienia w ruchu lub wymagają korzystania z drogi w sposób szczególny, mogą się odbywać pod warunkiem zapewnienia bezpieczeństwa porządku podczas trwania imprezy oraz uzyskania zezwolenia na jej przeprowadzenie ${ }^{37}$.

Jednoznacznie wynika z tego, iż organizator, uzyskując pozwolenie oraz pozytywną opinię od komendanta wojewódzkiego policji, spełnił przesłanki pozwalające mu na zorganizowanie imprezy. Przepisy ustawy o bezpieczeństwie imprez masowych są dużo bardziej restrykcyjne i zobowiązują do większej dbałości o bezpieczeństwo. Przykładem jest konieczność wyznaczenia kierownika do spraw bezpieczeństwa. Osoba ta musi być wykwalifikowana. Należy zwrócić uwagę, iż współpraca z policją w takiej sytuacji jest konieczna. Kontakt pomiędzy kierownikiem do spraw bezpieczeństwa a policją musi być stały podczas przebiegu imprezy masowej. Zadania funkcjonariuszy na widowisku z zajęciem pasa ruchu drogowego ograniczają się zaś do zapewnienia bezpieczeństwa ruchu na drodze. Odpowiednia łączność ze służbami, miejsce dowodzenia czy też oznakowanie

${ }^{32}$ Dz.U. z 2018 r., poz. 2142.

33 Dz.U. z 2020 r., poz. 110.

${ }^{34}$ Dz.U. z 2019 r., poz. 1580.

${ }^{35}$ Dz.U. z 2018 r., poz. 1983.

${ }^{36}$ S. Jadczak, Czemu nie impreza masowa? Gdański koncert zorganizowano na podstawie prawa drogowego, https://www.tvn24.pl/wiadomosci-z-kraju,3/organizacja-finalu-wosp-w-gdansku-jakie-przepisy-zastosowano,900368.html [dostęp: 25.11.2019].

${ }^{37}$ Ustawa z dnia 20 czerwca 1997 r. Prawo o ruchu drogowym. 
terenu imprezy to dodatkowe wymogi ustawy o bezpieczeństwie imprez masowych. Można pokusić się o stwierdzenie, iż Regionalne Centrum Wolontariatu w Gdańsku ,pposzło na łatwiznę". Zorganizowane przedsięwzięcie było tragiczne w skutkach. 13 stycznia 2019 roku odbył się 27. Finał WOŚP, na którym prezydent miasta Paweł Adamowicz zginął w wyniku ataku nożownika ${ }^{38}$. Koncert nie miał statusu imprezy masowej, a pozwolenie na nią zostało wydane z upoważnienia zmarłego tragicznie prezydenta. Temat jest bardzo kontrowersyjny, ponieważ wydarzenie od wielu lat cieszy się bardzo dużym zainteresowaniem ze strony uczestników i gromadzi rzesze ludzi. Ważne jest więc, aby koncert był organizowany na zasadach określonych w ustawie o bezpieczeństwie imprez masowych. Koncert zabezpieczała Agencja Ochrony „Tajfun”. W jednym z wywiadów organizatorzy przyznali, że firma ta została zobowiązana do specjalnego podejścia do wydarzenia i zabezpieczania go jak imprezy masowej ${ }^{39}$.

Dlaczego jednak nie zastosowano przepisów o bezpieczeństwie imprez masowych? Dlaczego, pomimo świadomości organizatorów o wadze i rozmiarach wydarzenia, podjęto decyzję o zakwalifikowaniu koncertu do zupełnie innej grupy widowisk, niż należało? Czy Zespół do Zarządzania Ruchem Urzędu Miasta Gdańska nie powinien odmówić wydania pozwolenia na imprezę organizowaną w takiej właśnie formie? W związku ze zdarzeniami, jakie miały miejsce na 27. Finale WOŚP, nasuwa się wiele pytań, na które ciężko znaleźć odpowiedź. Może będzie to wystarczający sygnał dla ustawodawcy, aby jednak podjąć kolejne działania legislacyjne.

Następną bardzo kontrowersyjną kwestią jest sytuacja, w której organizatorem imprezy masowej jest sam organ upoważniony do wydawania zezwoleń na przeprowadzenie takiej imprezy. Dochodzi wówczas do tego, że to sam wnioskodawca rozpatruje swój wniosek ${ }^{40}$. Wedle ustawy o bezpieczeństwie imprez masowych organem właściwym do rozpatrywania wniosku o pozwolenie na przeprowadzenie imprezy masowej jest wójt, burmistrz lub prezydent miasta (w zależności od miejsca, w którym ma odbyć się impreza). Decyzje wydawane są przez urzędników z upoważnienia wspominanego organu ${ }^{41}$. Dochodzi zatem do sytuacji, kiedy to podwładny analizuje wniosek własnego szefa. Czy w takiej sytuacji jest w stanie zrobić to tak, jak należy, nie bojąc się o ewentualną utratę pracy w momencie, gdy decyzja będzie niezadowalająca?

Według badań przeprowadzonych przez NIK istnieje wiele wykroczeń związanych z wydawaniem zezwoleń na przeprowadzenie imprez masowych. W latach 2015-2017 skontrolowano pięć urzędów miast wojewódzkich, dziesięć urzędów miast na prawach powiatu i dziesięć urzędów innych miast. W szesnastu z nich pozwolenia zostawały wydawane, mimo iż wnioski były składane po terminie, co wpływa znacząco na zaburzenie bezpieczeństwa imprez masowych. Ponadto w 48\% skontrolowanych urzędów dopatrzono

${ }^{38}$ A. Warżawa, Finat WOŚP w Gdańsku nie byt zgłoszony jako impreza masowa, https://www. gosc.pl/doc/5284757.KGP-Final-WOSP-w-Gdansku-nie-byl-zgloszony-jako-impreza-masowa [dostęp: 25.11.2019].

${ }^{39}$ S. Jadczak, dz. cyt.

40 Art. 18 Ustawy z dnia 20 marca 2009 r. o bezpieczeństwie imprez masowych.

${ }^{41}$ W. Wytrążek, Kompetencje organów samorządu terytorialnego, [w:] P. Stanisz, M. Czuryk, K. Ostaszewski, J. Święcki (red.), Sprawność a legalność administracji publicznej w sferze ochrony porzadku i bezpieczeństwa publicznego, Katolicki Uniwersytet Lubelski, Lublin 2014, s. 608. 
się wykroczeń związanych z przekazaniem kopii wydanych zezwoleń policji, straży pożarnej i wojewodom. Część z nich nie została w ogóle przekazana, część została przekazana $\mathrm{w}$ nieodpowiednim terminie ${ }^{42}$. Są to z pewnością znaczące wykroczenia, które nie powinny mieć miejsca. Wojewodowie mają prawo do zakazania przeprowadzenia imprezy masowej, jeśli stan bezpieczeństwa zostanie uznany za zły. Muszą jednak wiedzieć o tym, iż ma się ona w ogóle odbyć. Nie istnieją żadne sankcje za zaniechanie tej procedury, choć wydaje się ona bardzo istotna.

Kolejnym przykładem niedociągnięć ustawy o bezpieczeństwie imprez masowych jest kwestia związana z alkoholem. Według prawa napoje o zawartości alkoholu nie większej niż 3,5\% mogą być sprzedawane i podawane na różnych wydarzeniach gromadzących ludzi, oprócz imprezy masowej podwyższonego ryzyka. Zgodnie z ustawą o wychowaniu w trzeźwości tylko podmioty mające odpowiednie zezwolenie mogą sprzedawać i podawać napoje alkoholowe. Tak więc w procedurze związanej z wydawaniem pozwolenia na przeprowadzenie imprezy masowej powinno być weryfikowane, czy podmioty te mają potrzebne zezwolenie ${ }^{43}$. Po przeprowadzonej kontroli Najwyższa Izba Kontroli zwróciła się do ministra odpowiedzialnego za sprawy wewnętrzne między innymi o doprecyzowanie regulacji dotyczących obecności alkoholu na imprezach masowych.

\section{Podsumowanie}

Przeprowadzona analiza ustawy o bezpieczeństwie imprez masowych wykazała, iż są zauważalne pewne luki prawne umożliwiające zarówno organizatorowi, jak i organom wydającym zezwolenia na przeprowadzenie imprez działania mogące znacząco wpływać na jakość bezpieczeństwa wydarzeń. Pierwszym przykładem było wykorzystanie przez inicjatora imprezy ustawy Prawo o ruchu drogowym w celu uproszczenia wszelkich procedur, mimo iż koncert można było zaliczyć do imprez masowych. Kolejnym przykładem były wykroczenia związane z wydawaniem przez właściwe do tego organy zezwoleń na przeprowadzenie wydarzeń. Zwrócono również uwagę na sytuację, kiedy wnioskodawca jest jednocześnie osobą rozpatrującą wniosek oraz podkreślono konsekwencje braku sankcji za nieprzekazanie wojewodzie kopii wydanego zezwolenia. Ostatnim z przykładów było niedoprecyzowanie kwestii związanych ze sprzedażą alkoholu na tego typu widowiskach. Wyszczególniona na początku tekstu teza została potwierdzona przez zaprezentowane treści: zachodzą przesłanki wskazujące na konieczność nowelizacji ustawy o bezpieczeństwie imprez masowych. Wybrane kontrowersje jednoznacznie obrazują niedoskonałość tego aktu prawnego.

${ }^{42}$ NIK, Masowy problem, https://www.nik.gov.pl/aktualnosci/bezpieczenstwo/masowy-problem. html [dostęp: 25.11.2019].

${ }_{43}$ Tamże. 


\section{Bibliografia}

Bańko M. (red.), Słownik języka polskiego PWN, t. 1, Wydawnictwo Naukowe PWN, Warszawa 2000.

Ciechanowicz J., Rzym - ludzie i budowle, Państwowy Instytut Wydawniczy, Warszawa 1987.

Council of Europe, European Convention on Spectator Violence and Misbehaviour at Sports Events and in particular at Football Matches, https://rm.coe.int/168007a086 [dostęp: 23.11.2019].

Daszkiewicz T., Twórca nowożytnych igrzysk olimpijskich, [w:] Pierre de Coubertin (red.), Oda do sportu, Spółka Wydawnicza Heliodor, Warszawa 1996.

Deberny K., Płoszaj K., Firek W., Błyszczacy sterowiec. Pierre de Coubertin o sporcie i olimpizmie, Polski Komitet Olimpijski, Warszawa 2013.

Dyduch L., Imprezy masowe i zgromadzenia $w$ sprawach publicznych - aspekty prawne i praktyczne, „Kwartalnik Policyjny” 2016, R. X, nr 4(39).

Jadczak S., Czemu nie impreza masowa? Gdański koncert zorganizowano na podstawie prawa drogowego, https://www.tvn24.pl/wiadomosci-z-kraju,3/organizacja-finalu-wosp-w-gdanskujakie-przepisy-zastosowano,900368.html [dostęp: 25.11.2019].

James S., Starożytny Rzym. Oto jedna z najwspanialszych cywilizacji świata i ludzie, którzy ja tworzyli - od cesarza do niewolnika, Arkady, Warszawa 1994.

Kąkol C., Prawnokarne aspekty bezpieczeństwa imprez masowych, CeDeWu, Warszawa 2019.

Kopczyk R., Bezpieczeństwo imprez masowych w świetle przepisów unijnych, http://robertgrzeszczak.bio.wpia.uw.edu.pl/files/2015/03/BEZPIECZE\%C5\%83STWO-IMPREZ-MASOWYCH-W-\%C5\%9AWIETLE-PRZEPIS\%C3\%93W R.-Kopczyk.pdf [dostęp: 23.11.2019].

Krawiec G., Tkacz S., Wentkowska A., Ustawa o bezpieczeństwie imprez masowych: wykładnia przepisów nowelizujacych w świetle regulacji europejskich, Biuro Rzecznika Praw Obywatelskich, Warszawa 2013.

Lipoński W., Historia sportu, Wydawnictwo Naukowe PWN, Warszawa 2018.

Miller S.G., Starożytni Olimpijczycy. Sportowe życie antycznej Grecji, Państwowy Instytut Wydawniczy, Warszawa 2004.

NIK, Masowy problem, https://www.nik.gov.pl/aktualnosci/bezpieczenstwo/masowy-problem. html [dostęp: 25.11.2019].

Osterloff W. K., Historia sportu, Instytut wydawniczy Nasza Księgarnia, Warszawa 1976.

Pieprzny S., Ura E., Udział organów administracji publicznej w zabezpieczaniu imprez masowych, [w:] ciż (red.), Bezpieczeństwo imprez masowych, RS Druk, Rzeszów 2012.

Polski Komitet Olimpijski, Igrzyska starożytne, https://www.olimpijski.pl/pl/78,igrzyska-starozytne.html [dostęp: 23.11.2019].

Porada Z., Starożytne i nowożytne igrzyska olimpijskie, Krajowa Agencja Wydawnicza, Kraków 1980.

Sejm VI kadencji, Uzasadnienie projektu ustawy o bezpieczeństwie imprez masowych, druk nr 1074, http://orka.sejm.gov.pl/Druki6ka.nsf/0/DA36C82C8CD734EDC12574DA002C0991/\$file/1074.pdf [dostęp: 25.11.2019]. 
Sitek B., Bezpieczeństwo imprez masowych $w$ antycznym Rzymie na tle współczesnych rozwiazań, „Studia Ełckie” 2011, nr 13.

Stańczyk J., Współczesne pojmowanie bezpieczeństwa, Instytut Studiów Politycznych Polskiej Akademii Nauk, Warszawa 1996.

Suski P., Zgromadzenia i imprezy masowe, wydanie 2, LexisNexis, Warszawa 2010.

Warżawa A., Finat WOŚP w Gdańsku nie byt zgłoszony jako impreza masowa, https://www. gosc.pl/doc/5284757.KGP-Final-WOSP-w-Gdansku-nie-byl-zgloszony-jako-impreza-masowa [dostęp: 25.11.2019].

Wykrent D., Przeglad prawa i administracji. Wybrane aspekty prawne zapewnienia bezpieczeństwa imprez masowych jako jednego z warunków bezpieczeństwa publicznego, Wydawnictwo Uniwersytetu Wrocławskiego, Wrocław 2016.

Wytrążek W., Kompetencje organów samorząu terytorialnego, [w:] P. Stanisz, M. Czuryk, K. Ostaszewski, J. Święcki (red.), Sprawność a legalność administracji publicznej w sferze ochrony porzadku i bezpieczeństwa publicznego, Katolicki Uniwersytet Lubelski, Lublin 2014.

\section{Akty prawne}

Konstytucja Rzeczpospolitej Polskiej z dnia 2 kwietnia 1997 r., Dz.U. z 1997 r. nr 78, poz. 483 ze zm.

Ustawa z dnia 25 października 1991 r. o organizowaniu i prowadzeniu działalności kulturalnej, tekst jedn. Dz.U. z 2018 r., poz. 1983.

Ustawa z dnia 20 czerwca 1997 r. Prawo o ruchu drogowym, tekst jedn. Dz.U. z 2020 r., poz. 110.

Ustawa z dnia 22 sierpnia 1997 r. o ochronie osób i mienia, tekst jedn. Dz.U. z 2018 r., poz. 2142.

Ustawa z dnia 3 lipca 2002 r. Prawo lotnicze, tekst jedn. Dz.U. z 2019 r., poz. 1580.

Ustawa z dnia 20 marca 2009 r. o bezpieczeństwie imprez masowych, tekst jedn. Dz.U. z 2019 r., poz. 2171. 